\title{
Sistem Informasi Pengukuran Produktivitas Hotel di Kabupaten Jember Menggunakan Metode OMAX (Objective Matrix) dan AHP (Analytical Hierarchy Process) (Studi Kasus Hotel Istana)
}

\author{
(Information System For Productivity Measurement of Hotel In Jember District Using OMAX \\ (Objective Matrix) And AHP (Analytical Hierarchy Process) \\ (Istana Hotel Case Study))
}

\author{
Suci Nur Ramadhani, Antonius Cahya Prihandoko, Nelly Oktavia Adiwijaya \\ Sistem Informasi, Program Studi Sistem Informasi, Universitas Jember (UNEJ) \\ Jln. Kalimantan 37, Jember 68121 \\ E-mail: antoniuscp@gmail.com
}

\begin{abstract}
Abstrak
Sistem informasi pengukuran produktivitas hotel di kabupaten Jember menggunakan metode OMAX dan AHP merupakan sistem yang bertujuan untuk melakukan perhitungan produktivitas hotel dalam suatu periode dan mengetahui faktor-faktor yang menyebabkan peningkatan atau penurunan produktivitas sehingga program perbaikan dapat dilakukan ketika produktivitas mengalami penurunan. Metode OMAX digunakan untuk menghitung nilai indeks produktivitas pada periode pengukuran. Sedangkan metode AHP digunakan untuk menentukan nilai bobot pada indikator pengukuran. Sistem informasi pengukuran produktivitas hotel ini dibangun berbasis website agar dapat digunakan dengan mudah oleh manager dan setiap departemen yang ada. Sistem ini dibangun mengadopsi model waterfall. Hasil dari penelitian ini, sistem dapat melakukan perhitungan produktivitas dan menampilkan faktor yang mempengaruhi nilai produktivitas tersebut sehingga dapat membantu manager dalam mengontrol produktivitas. Dengan menggunakan sistem pengukuran produktivitas hotel ini dapat diketahui bahwa pada bulan Oktober 2016 indeks produktivitas mengalami peningkatan sebesar 7,8\%. Faktor-faktor yang menyebabkan produktivitas meningkat dibanding periode sebelumnya yaitu rasio hunian kamar, rasio perawatan kamar dan rasio pelayanan $F \& B$.
\end{abstract}

Kata Kunci: Pengukuran Produktivitas, Objective Matrix, AHP

\begin{abstract}
Information system for productivity measurement of hotel in Jember district using OMAX and AHP methods is a system that aimed to calculation the hotel productivity in a period and identify the factors that caused an increase or decrease of productivity in order to the improvement can be done when the productivity decreased. OMAX method is used to count productivity index in measuring period. While the method of AHP is used to determine the weight value on the measurement indicators. Information system for productivity measurement of hotel was built based website that can be used easily by manager and every existed departments. The system was built by adopting the waterfall model. The result of this research, system can calculate productivity and display of factors affect productivity's value in order to help manager controlling productivity. By using this system, showed that in October 2016 productivity index increased by 7,8\%. The factors that lead to increase productivity are room occupancy ratio, treatment rooms ratio and $F \& B$ services ratio.
\end{abstract}

Keywords: Productivity Measurement, Objective Matrix, AHP

\section{PENDAHULUAN}

Perkembangan sektor jasa pelayanan perhotelan pada saat ini cukup berkembang pesat. Meningkatnya jumlah hotel dari tahun ke tahun mengakibatkan ketatnya persaingan yang ditimbulkan. Kondisi persaingan yang ketat memacu setiap pihak manajemen hotel untuk menemukan solusi yang dapat meningkatkan daya saing. Hotel harus mampu melakukan berbagai program peningkatan manajemen agar dapat meningkatkan daya saing yang kompetitif tanpa harus mengurangi pelayanan kepada pelanggan, dimana kualitas pelayanan tetap menjadi prioritas utama. Agar tujuan dapat tercapai, segenap sumber daya organisasi harus diarahkan untuk fokus memberikan pelayanan yang terbaik kepada setiap pengunjung.

Secara umum hotel yang memiliki tingkat produktivitas lebih tinggi dari pesaingnya memiliki tingkat keuntungan yang lebih tinggi, oleh karena itu suatu hotel perlu mempertahankan atau meningkatkan produktivitasnya. Hotel dapat mengontrol atau melihat produktivitasnya dengan cara melakukan pengukuran produktivitas. Hasil pengukuran tersebut digunakan sebagai pertimbangan untuk mengevaluasi faktor apa saja yang menyebabkan penurunan ataupun peningkatan produktivitas, sehingga programprogram perbaikan dapat dilakukan untuk dapat meningkatkan produktivitas diperiode yang akan datang, sehingga dapat meningkatkan daya saing yang kompetitif dengan hotel-hotel lainnya. 
Hotel istana yang menjadi objek studi kasus pada penelitian ini merupakan salah satu hotel non bintang yang berada di kabupaten Jember yang memiliki beberapa departement yaitu Front Office, Housekeeping, Food \& Beverage, Engineering, Marketing dan Human Resource Development (HRD). Setiap departement dapat mengalami peningkatan maupun penurunan kinerja, sehingga hal tersebut juga berdampak pada produktivitas hotel. Evaluasi sangat diperlukan ketika suatu departement mengalami penurunan terhadap kinerjanya, oleh karena itu untuk mengetahui departemen apa saja yang menyebabkan penurunan kinerja yang berdampak pada penurunan produktivitas hotel diperlukan suatu teknik pengukuran. Hasil pengukuran produktivitas dapat dijadikan sebagai acuan untuk mengevaluasi departement tersebut agar dapat meningkatkan kinerjanya. Berdasarkan ulasan mengenai produktivitas diatas, diperlukan suatu sistem informasi pengukuran produktivitas yang dapat mengukur produktivitas pada setiap periode dan dapat mengetahui seberapa baik kinerja dari setiap departement yang ada. Pada penelitian ini dibutuhkan metode OMAX dan AHP. Metode OMAX digunakan untuk mengukur produktivitas, karena pengukuran produktivitas menggunakan OMAX menggunakan gabungkan kriteria-kriteria produktivitas yang terpadu dan berhubungan satu sama lain. Metode ini melibatkan seluruh devisi dalam suatu organisasi, sedangkan AHP (Analytical Hierarchy Process) digunakan untuk menentukan bobot pada indikator pengukuran yang akan digunakan pada salah satu tahap dalam melakukan perhitungan produktivitas menggunakan OMAX.

Penelitian terhadap pengukuran produktivitas pernah dilakukan pada beberapa penelitian, seperti pada penelitian dengan judul "Pendekatan Model Objective Matrix-AHP untuk Pengambilan Keputusan Penilaian Kinerja Pelayanan pada Kantor Kelurahan" (Fiati, 2015). Penelitian ini menjelaskan bagaimana suatu organisasi melakukan pengukuran kinerja terhadap organisasi tersebut agar dapat dijadikan sebagai bahan pertimbangan untuk mengetahui faktor apa saja yang menyebabkan peningkatan maupun penurunan kinerja. Penelitian ini bertujuan untuk membantu para pimpinan dalam mengambil langkah untuk meningkatkan kinerja pelayanan masyarakat pada kantor kelurahan. Metode objective matrix membantu pimpinan untuk dapat mengetahui faktor yang mengakibatkan peningkatan maupun penurunan kinerja terhadap pelayanan pada kantor kelurahan. Setiap kriteria kinerja memiliki bobot sesuai dengan tingkat kepentingannya terhadap tujuan organisasi. Pembobotan dilakukan dengan menggunakan metode Analytical Hierarchy Process (AHP), dimana setiap kriteria memiliki tingkat kepentingan yang berbeda dan saling dibandingkan dengan kriteria lainnya. Hasil dari penelitian ini yaitu perencanaan perbaikan kinerja dilakukan agar kinerja pelayanan, jam kerja dan karyawan dapat mencapai sasaran yang telah ditetapkan dan hasil perbaikan digunakan sebagai dasar untuk meningkatkan kinerja pada perusahaan.

Penelitian lain juga pernah dilakukan untuk mengukur produktivitas dengan judul "Analisis Produktivitas dengan Metode Objective Matrix (OMAX) di PT. X" (Agustina \& Riana, 2011). Penelitian dilakukan dengan menggunakan metode objective matrix untuk mengukur produktivitas dan AHP untuk pemberian bobot pada setiap kriteria yang ada. Penelitian tersebut dilakukan untuk mengukur produktivitas dari PT. X yang merupakan pabrik gula yang dimiliki oleh pemerintah. Hasil produksi pabrik pada tahun 2010 mengalami penurunan dibanding tahun-tahun sebelumnya. Oleh karena itu pengukuran produktivitas dilakukan agar dapat dijadikan sebagai bahan pertimbangan untuk mengetahui faktor-faktor apa yang menyebabkan penurunan produktivitas dan usulan rencana apa yang harus dilakukan agar produktivitas perusahaan mengalami peningkatan untuk masa yang akan datang.

\section{Tinjauan Pustaka}

\section{Objective Matrix (OMAX)}

Objective matrix merupakan suatu sistem pengukuran produktivitas parsial yang dikembangkan untuk memantau produktivitas pada setiap bagian perusahaan dengan kriteria produktivitas yang sesuai dengan keberadaan bagian tersebut. Metode ini memiliki konsep pengukuran yang menggabungkan beberapa kriteria kinerja kelompok kerja kedalam sebuah matrik. Masing-masing kriteria memiliki bobot sesuai dengan tingkat kepentingannya terhadap suatu organisasi.

Objective matrix pada penelitian ini digunakan untuk menghitung produktivitas hotel pada setiap periode yang telah ditentukan. Menurut (Silalahi, 2014), langkah-langkah implementasi metode objective matrix adalah sebagai berikut:

\section{Penentuan Kriteria Kinerja}

Penentuan kriteria ditetapkan berdasarkan hasil analis terhadap faktor yang dapat mempengaruhi produktivitas sehingga dapat menyebabkan kenaikan maupun penurunan produktivitas.

\section{Perhitungan rasio produktivitas}

Rasio produktivitas merupakan perbandingan antar kinerja yang telah dilakukan dengan hasil yang diperoleh dari kinerja tersebut. Untuk dapat menghitung nilai rasio maka diperlukan nilai data yang aktual dari kriteria-kriteria yang telah ditentukan yang diperoleh dari instansi bersangkutan selama beberapa periode.

\section{Menghitung kenaikan setiap level}

Nilai kenaikan setiap level dalam tabel OMAX dimulai dari level 0 sampai dengan level 10 sehingga terdapat 11 tingkatan untuk setiap kriteria. Level 0 merupakan level terendah, level 3 merupakan dasar atau nilai awal pada saat pengukuran pertama kali dilakukan, sedangkan level 10 merupakan level tertinggi dari hasil pengukuran produktivitas. Nilai kenaikan setiap level di gunakan sebagai acuan untuk pemberian skor yang diperoleh sesuai dengan pencapaian setiap rasio yang dihitung.

\section{Pembobotan}

Pemberian bobot dilakukan karena setiap kriteria memiliki tingkat pengaruh yang yang berbeda-beda dalam perhitungan produktivitas. Pada penelitian ini pemberian nilai bobot dilakukan dengan menggunakan metode Analytic Hierarchy Process (AHP).

\section{Menghitung indeks produktivitas}

Indeks produktivitas merupakan hasil perbandingan antara periode yang diukur (periode saat ini) dengan periode sebelumnya. Tujuan dari perhitungan indeks 
produktivitas adalah untuk mengetahui apakah produktivitas hotel sedang mengalami peningkatan atau penurunan.

\section{Analytic Hierarchy Process (AHP)}

Metode AHP dikembangkan oleh Thomas L. Saaty, dari Universitas Pittsburg. Metode AHP dapat memecah masalah kompleks ke dalam kelompok-kelompok yang kemudian diatur menjadi suatu bentuk hirarki sehingga permasalahan akan tampak lebih terstruktur dan sistematis.

AHP pada penelitian ini digunakan untuk menghitung bobot dari setiap kriteria yang menjadi aspek pengukuran. Menurut Juliyanti et al (2011), langkah-langkah implementasi metode AHP adalah sebagai berikut:

\section{Penyusunan Hirarki (Decomposition)}

Proses penyusunan hirarki merupakan proses dimana permasalahan yang ada akan disusun menjadi model hirarki yaitu dengan memecah suatu persoalan menjadi elemenelemen yang terpisah.

\section{Penyusunan dan Penetapan Prioritas (Synthesis of Priority)}

Penyusunan dan penetapan prioritas merupakan tahapan yang dilakukan untuk memperoleh suatu nilai prioritas dari kriteria-kriteria yang digunakan dalam mendukung tercapainya tujuan. Berikut merupakan tahapan-tahapan yang dilakukan dalam menentukan nilai prioritas pada setiap kriteria.

\section{Perbandingan Penilaian (Comparative Judgement)}

Perbandingan Penilaian yaitu membuat suatu penilaian tentang kepentingan antara dua kriteria yang kemudian disajikan dalam bentuk matrik perbandingan berpasangan. Untuk dapat membuat matrik perbandingan berpasangan maka harus dapat menentukan diantara dua kriteria yang dianggap paling penting, selain itu juga menentukan seberapa penting kriteria satu dengan kriteria lainnya.

Seluruh prioritas yang ada dibandingkan satu sama lain secara berpasangan dan diberi bobot berupa skala dari 1 sampai dengan 9. Skala perbandingan tingkat kepentingan pada metode AHP dapat dilihat pada Tabel 2.1

\section{Konsistensi Logis (Logical Consistency)}

Metode AHP memiliki perbedaan asumsi dengan metode pengambilan keputusan yang lain yaitu tidak adanya syarat konsistensi mutlak dimana metode ini menggunakan persepsi manusia sebagai masukan. Keterbatasan manusia tentu saja dapat menyebabkan munculnya nilai yang tidak konsisten dalam menyatakan persepsinya, apalagi jika membandingkan banyak elemen. Konsistensi menunjukkan intensitas relasi antar elemen didasarkan pada suatu kriteria tertentu.

Index konsistensi (CI) dapat diperoleh dari

$$
\mathrm{CI}=\begin{gathered}
\text { jumlah kriteria }(n-1) \\
\text { zmaks-jumlaj kriteria }(n) \frac{i}{\dot{6}}
\end{gathered}
$$

Rasio konsistensi (CR) dapat diperoleh dari

$$
\mathrm{CR}=\frac{C I}{C R},(R I=\text { Random Index })
$$

Tabel 2.1 Skala Perbandingan Tingkat Kepentingan

\begin{tabular}{cll}
\hline $\begin{array}{c}\text { Perbandingan } \\
\text { nilai relative } \\
\text { antar kriteria A } \\
\text { dan kriteria B }\end{array}$ & $\begin{array}{c}\text { Definisi } \\
\text { Penilaian }\end{array}$ & \multicolumn{1}{c}{ Keterangan } \\
\hline 1 & Sama penting & $\begin{array}{l}\text { Dua kriteria (A dan B) memiliki tingkat } \\
\text { kepentingan yang sama dalam memenuhi tujuan }\end{array}$ \\
\hline 3 & $\begin{array}{l}\text { Sedikit lebih } \\
\text { penting }\end{array}$ & $\begin{array}{l}\text { Kriteria A sedikit lebih penting dibandingkan } \\
\text { kriteria B dalam memenuhi tujuan }\end{array}$ \\
\hline 5 & Lebih penting & $\begin{array}{l}\text { Kriteria A memiliki tingkat kepentingan yang } \\
\text { cukup besar dibandingkan kriteria B dalam } \\
\text { memenuhi tujuan }\end{array}$ \\
\hline 7 & Sangat penting & $\begin{array}{l}\text { Kriteria A memiliki tingkat kepentingan sangat } \\
\text { besar dibandingkan kriteria B dalam memenuhi } \\
\text { tujuan }\end{array}$ \\
\hline $2,4,6,8$ & Nilai antara & $\begin{array}{l}\text { Kriteria A memiliki tingkat kepentingan jauh } \\
\text { lebih besar dibandingkan kriteria B dalam } \\
\text { memenuhi tujuan }\end{array}$ \\
\hline Kebalikan & $\begin{array}{l}\text { Jika aktivitas A mendapatkan satu angka dibandingkan aktivitas B, } \\
\text { maka B memiliki nilai kebalikannya dibandingkan dengan A. }\end{array}$ \\
\hline
\end{tabular}

Sumber: (Saaty, 1994)

\section{METODE PENELITIAN}

\section{Tahapan Penelitian}

Tahapan penelitian ini meliputi tahap pengumpulan data dan tahap analisis data. Penelitian dimulai dengan mencari studi literatur, menentukan tempat penelitian dan wawancara yang kemudian dilanjutkan ke analisis data dan pembuatan sistem untuk merumuskan analisis kebutuhan dari sistem. Setelah analisis kebutuhan terpenuhi, proses selanjutnya yaitu perancangan dan implementasi meliputi desain, coding kemudian testing aplikasi yang dibangun. Jika terjadi error maka akan dilakukan perbaikan sistem. Tahap terakhir yaitu penyusunan laporan.

\section{Perancangan sistem}

Perancangan sistem pada penelitian ini mengadopsi metode waterfall. Menurut Pressman (2001), Terdapat 5 tahapan pada model waterfall, yaitu analisis kebutuhan (requirements), desain, implementasi dan perawatan (maintenance).

\section{Analisis Kebutuhan}

Analisis kebutuhan merupakan tahap untuk mengumpulkan data, informasi, serta mencari kebutuhan fungsional dan non fungsional sistem. Pada tahap ini, peneliti mencari permasalahan yang ada untuk dapat dianalisis kebutuhan yang diperlukan, sebagai solusi dari permasalahan yang muncul. Data-data yang telah didapat kemudian dikelompokkan menjadi kebutuhan fungsional dan non-fungsional sistem. Hasil analisa tersebut sangat mempengaruhi fungsionalitas sistem yang dibangun untuk dapat digunakan sesuai dengan fungsi dan kebutuhan pengguna.

\section{Desain Sistem}

Tahapan yang dilakukan setelah melakukan analisis kebutuhan sistem yaitu tahap perencanaan pembangunan sistem yang dapat digambarkan dengan desain sistem. sistem informasi pengukuran produktivitas hotel ini meliputi business process, use case diagram, scenario, activity diagram, sequence diagram, class diagram, dan entity relationship diagram. Berikut Use case diagram dari sistem informasi pengukuran produktivitas hotel dapat dilihat pada Gambar 3.1 


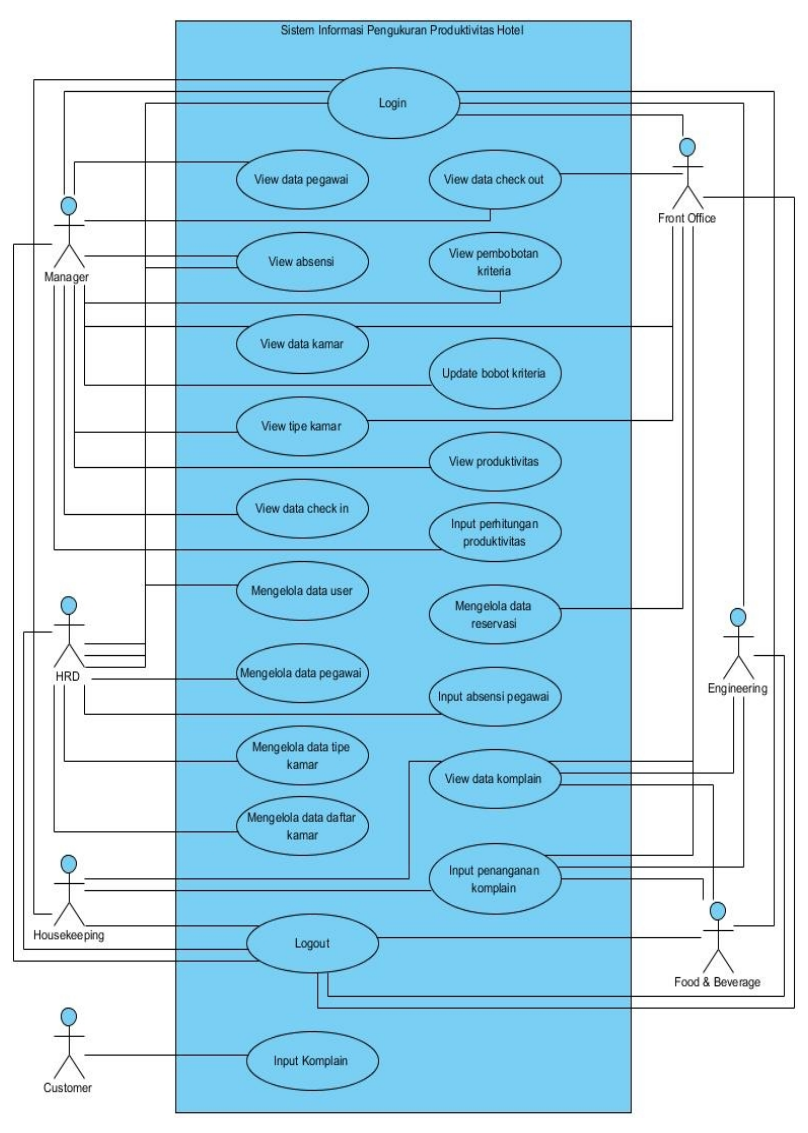

Gambar 3.1 Use Case Diagram

\section{Implementasi Sistem}

Desain yang telah dibuat akan diimplementasikan ke dalam kode program. Beberapa hal yang dilakukan dalam tahap implementasi antara lain:

a. Penulisan kode program (coding) menggunakan bahasa pemrograman Page Hyper Text Pre-Processor (PHP) dengan bantuan framework Code Igniter (CI).

b. Manajemen basis data menggunakan DBMS MySQL.

\section{Pengujian Sistem}

Pengujian digunakan untuk mengetahui sejauh mana sistem ini dapat berjalan. Testing berfungsi untuk mengetahui apakah sistem ini dapat berfungsi dengan baik sesuai dengan yang diharapkan. Serta untuk mengetahui letak kekurangan yang ada pada sistem ini. Metode pengujian yang digunakan yakni, metode black box dan white box.

\section{Pemeliharaan Sistem}

Pemeliharaan merupakan proses perawatan sistem setelah sistem digunakan oleh pengguna. Pemeliharaan dilakukan dengan mengecek kinerja sistem secara berkala. Pengecekan dilakukan apakah kinerja sistem masih berjalan dengan baik dan memperbaiki apakah terdapat kerusakan atau tidak.

\section{HASIL PENELITIAN}

Pada bab ini akan dipaparkan hasil dan pembahasan sistem selama dilakukannya penelitian yang mencakup setiap tahap implementasi dan pengujian sistem informasi pengukuran produktivitas hotel di kabupaten Jember menggunakan metode OMAX dan AHP.

Hasil Penerapan Perhitungan Metode Analytic Hierarchy Process (AHP)

Data-data yang digunakan dalam perhitungan pengukuran produktivitas hotel menggunakan metode OMAX dan AHP adalah sebagai berikut.

\section{Data Kriteria}

Data kriteria merupakan data indikator pengukuran yang telah disesuaikan dengan faktor yang dapat mempengaruhi produktivitas hotel sesuai dengan departemen yang ada pada hotel Istana. Data kriteria yang digunakan dapat dilihat pada Tabel 4.1 .

\begin{tabular}{|c|c|}
\hline No. & Kriteria \\
\hline 1 & Rasio Hunian kamar (Departemen Marketing) \\
\hline 2 & $\begin{array}{l}\text { Rasio Perawatan Kamar (Departemen } \\
\text { Housekeeping) }\end{array}$ \\
\hline 3 & $\begin{array}{l}\text { Rasio Pelayanan Food \& Beverage (Departemen } \\
\text { Food \& Beverage) }\end{array}$ \\
\hline 4 & Rasio Absensi Karyawan (Departemen HRD) \\
\hline 5 & $\begin{array}{l}\text { Rasio Perbaikan Engineering (Departemen } \\
\text { Engineering) }\end{array}$ \\
\hline
\end{tabular}

\section{Data Pembobotan Kriteria Menggunakan Metode AHP}

Data nilai pembobotan kriteria merupakan nilai hasil perhitungan pembobotan menggunakan metode AHP yang didapat berdasarkan wawancara dengan pakar yang dilakukan. Nilai Pembobotan Kriteria dapat dilihat pada Tabel 4.2

Tabel 4.2 Data nilai Pembobotan Kriteria

\begin{tabular}{ccc}
\hline Nama Rasio & Departemen & Bobot \\
\hline $\begin{array}{c}\text { Rasio Hunian } \\
\text { kamar }\end{array}$ & Marketing & 0,548 \\
\hline $\begin{array}{c}\text { Rasio Perawatan } \\
\text { Kamar }\end{array}$ & Housekeeping & 0,063 \\
\hline $\begin{array}{c}\text { Rasio Pelayanan } \\
\text { F\&B }\end{array}$ & Food \& Beverage & 0,086 \\
\hline $\begin{array}{c}\text { Rasio Absensi } \\
\text { Karyawan }\end{array}$ & HRD & 0,250 \\
\hline $\begin{array}{c}\text { Rasio Perbaikan } \\
\text { Engineering }\end{array}$ & Engineering & 0,053 \\
\hline
\end{tabular}

\section{Hasil Penerapan Perhitungan Objective Matrix}

Dalam perhitungan produktivitas, kriteria-kriteria yang telah ditentukan dituangkan dalam bentuk rasio. Pada tabel 4.3 berikut merupakan tabel rasio kriteria. 
Tabel 4.3 Kriteria Rasio

\begin{tabular}{|c|c|c|}
\hline $\begin{array}{l}\text { Nama } \\
\text { Rasio }\end{array}$ & Rumus Rasio & Bobot \\
\hline $\begin{array}{l}\text { Rasio } \\
\text { Hunian } \\
\text { kamar }\end{array}$ & $\begin{array}{c}\text { Total kamar tesedia } \\
\text { Jumlah kamar yang dihuni } \frac{\dot{b}}{\dot{i}}\end{array}$ & 0,548 \\
\hline $\begin{array}{l}\text { Rasio } \\
\text { Perawatan } \\
\text { Kamar }\end{array}$ & $\begin{array}{l}\text { Jumlah hari perawatan kamar } \\
\text { Jumlah kamar yang dibersihkan! }\end{array}$ & 0,063 \\
\hline $\begin{array}{l}\text { Rasio } \\
\text { Pelayanan } \\
\text { F\&B }\end{array}$ & $\begin{array}{c}\text { Jumlah pengadaan bahan baku } \\
\text { Jumlah porsi } F \wedge B \frac{\dot{i}}{i}\end{array}$ & 0,086 \\
\hline $\begin{array}{l}\text { Rasio } \\
\text { Absensi } \\
\text { Karyawan }\end{array}$ & $\frac{\text { Jumlah absen karyawan }}{\text { Jumlah karyawan }} X 10$ & 0,250 \\
\hline $\begin{array}{l}\text { Rasio } \\
\text { Perbaikan } \\
\text { Engineeri } \\
n g\end{array}$ & $\begin{array}{l}\text { Total keruskan sarana } \\
\text { komplain perbaikan oleh engine }\end{array}$ & 0,053 \\
\hline
\end{tabular}

Setelah menentukan rasio kriteria, dilakukan perhitungan nilai rasio pada setiap kriteria sesuai dengan rumus pada tabel 4.3. Data yang akan dihitung merupakan data aktual yang telah dicapai oleh hotel selama periode tertentu. Sehingga diperoleh nilai rasio pada setiap kriteria dan dapat menentukan nilai kenaikan setiap level pada matrix omax. Pada tabel 4.4 merupakan tabel matrik OMAX perhitungan produktivitas hotel pada bulan November 2016. Pada tabel tersebut diperoleh nilai indikator performansi. Indikator performansi digunakan untuk menghitung nilai indeks produktivitas. Untuk menghitung indeks produktivitas menggunakan rumus sebagai berikut:

$$
\begin{aligned}
I P= & \frac{\text { Current }- \text { Previous }}{\text { Previous }} \times 100 \\
& =\frac{702,3-651,5}{651,5} \times 100 \\
& =7,8
\end{aligned}
$$

Pada perhitungan diatas, angka 651,5 merupakan hasil perhitungan indikator performansi pada periode sebelumnya yaitu bulan Oktober. Produktivitas hotel pada bulan November mengalami peningkatan sebesar 7,8\% dibanding bulan Oktober, hal tersebut terjadi karena pada rasio satu, dua dan tiga yaitu rasio hunian kamar (departemen marketing), rasio perawatan kamar (departemen housekeeping), rasio pelayanan $F \& B$ (departemen food \& beverage) mengalami kinerja yang sangat baik selama periode pengukuran sedangkan pada rasio empat dan lima mengalami kinerja yang buruk sehingga evaluasi atau program perbaikan dilakukan pada kedua faktor yang memiliki kinerja buruk tersebut. Hasil peritungan omax lebih jelas dapat dilihat pada Tabel 4.4
Tabel 4.4 Matrix OMAX

\begin{tabular}{ccccccc}
\hline Tabel & \multicolumn{5}{c}{ Rasio Produktivitas hotel bulan November 2016 } \\
\cline { 2 - 7 } Omax & rasio 1 & rasio 2 & rasio 3 & rasio 4 & rasio 5 & \\
\hline kala rasio & 73,73 & 3096,67 & 0,00244 & 6,25 & 80 & $\begin{array}{c}\text { Nilai aktual } \\
\text { produktivitas }\end{array}$ \\
\hline 10 & 73,73 & 3096,67 & 0,00244 & 0 & 100 & Sangat baik \\
\hline 9 & 71,01 & 2981,85 & 0,00240 & 0,26 & 99,46 & Sangat baik \\
\hline 8 & 68,30 & 2867,03 & 0,00236 & 0,52 & 98,93 & Baik \\
\hline 7 & 65,58 & 2752,21 & 0,00231 & 0,78 & 98,39 & Baik \\
\hline 6 & 62,87 & 2637,40 & 0,00227 & 1,04 & 97,86 & Baik \\
\hline 5 & 60,15 & 2522,58 & 0,00222 & 1,30 & 97,32 & Cukup \\
\hline 4 & 57,43 & 2407,76 & 0,00218 & 1,56 & 96,79 & Cukup \\
\hline 3 & 54,72 & 2292,95 & 0,00213 & 1,82 & 96,25 & Cukup \\
\hline 2 & 49,84 & 2089,74 & 0,00203 & 3,30 & 89,17 & Buruk \\
\hline 1 & 44,96 & 1886,54 & 0,00193 & 4,77 & 82,08 & Buruk \\
\hline 0 & 40,08 & 1683,33 & 0,00183 & 6,25 & 75 & Buruk \\
\hline Skor & 10 & 10 & 10 & 0 & 1 & \\
\hline Bobot & 54,8 & 6,3 & 8,6 & 25 & 5,3 & \\
\hline $\begin{array}{l}\text { Indikator } \\
\text { performansi }\end{array}$ & 548 & 63 & 86 & 0 & 53 & 702,3 \\
\hline
\end{tabular}

Hasil Pembuatan Sistem Informasi Pengukuran Produktivitas Hotel di Kabupaten Jember Menggunakan OMAX dan AHP

Hasil sistem informasi pengukuran produktivitas hotel menggunakan metode objective matrix dan AHP yang dibangun dapat di akses oleh tujuh user yaitu manager, $\mathrm{HRD}$, front office, engineering, housekeeping, food \& beverage dan customer. Berikut fitur pembobotan AHP dan fitur hasil perhitungan produktivitas

4.3.1 Fitur Pembobotan AHP

Fitur pembobotan AHP merupakan fitur yang dilakukan oleh manager untuk mengelola pembobotan data kriteria menggunakan metode AHP. Tampilan halaman data indikator pengukuran dapat dilihat pada Gambar 4.1 dan Gambar 4.2

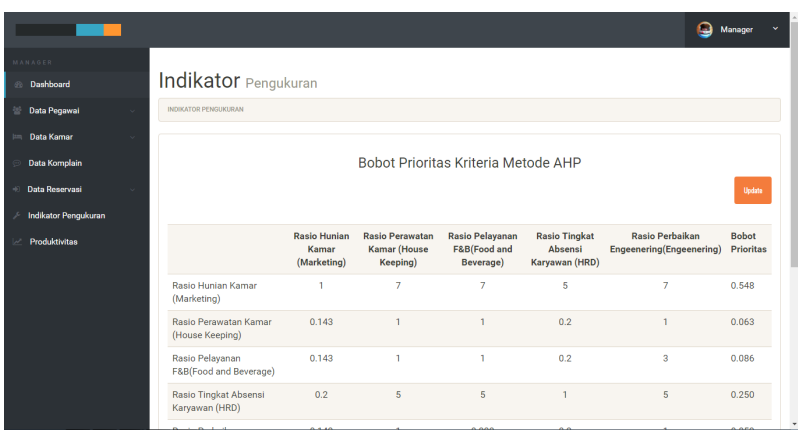

Gambar 4.1 Fitur pembobotan kriteria(1)

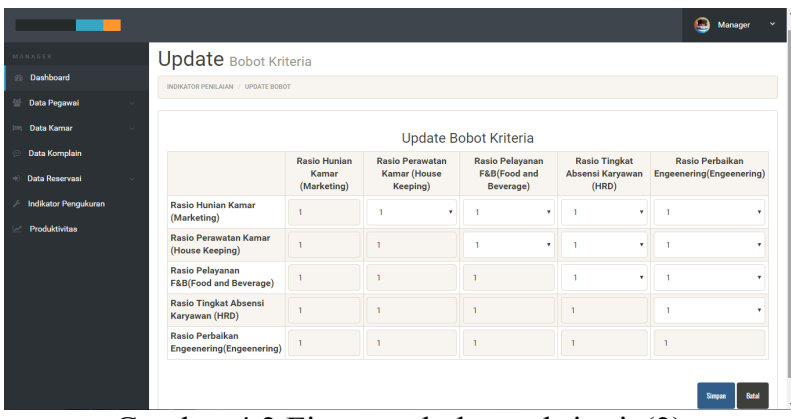

Gambar 4.2 Fitur pembobotan kriteria(2) 


\section{Fitur Hasil Pengukuran Produktivitas}

Fitur view produktivitas merupakan fitur untuk melihat produktivitas dari hotel yang sudah pernah dihitung, fitur ini dapat diakses oleh manager. Terdapat tombol detail produktivitas untuk melihat detail produktivitas pada periode tertentu. Tampilan halaman produktivitas dapat dilihat pada Gambar 4.3 dan halaman detail produktivitas dapat dilihat pada Gambar 4.4

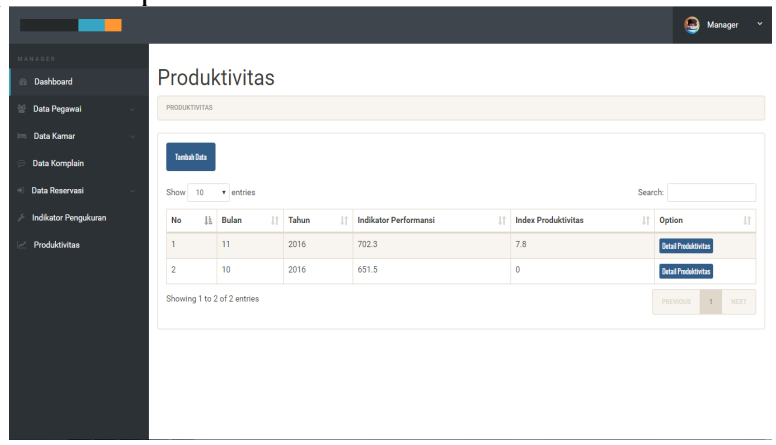

Gambar 4.3 Halaman view produktivitas(1)

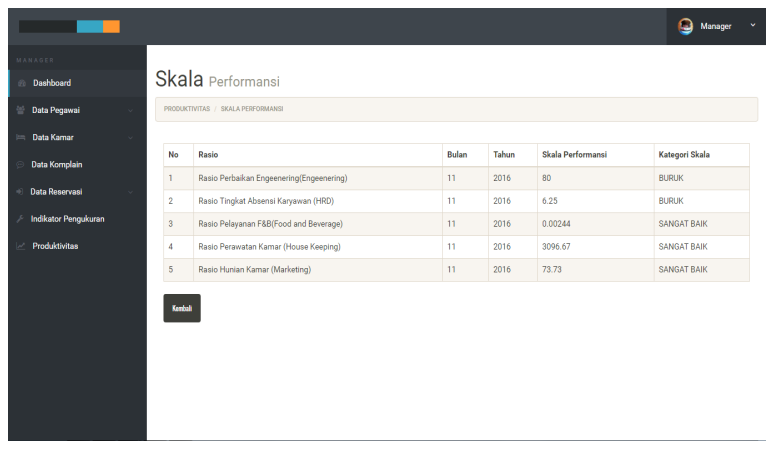

Gambar 4.4 Halaman view produktivitas(2)

Pembahasan Pada Sistem Informasi Pengukuran Produktivitas Hotel di Kabupaten Jember Menggunakan Metode OMAX dan AHP

Pembahasan ini menjelaskan hasil dari implementasi serta hasil perancangan dan pembangunan sistem informasi pengukuran produktivitas hotel. Hasil perhitungan manual dan perhitungan sistem memiliki tingkat akurasi yang tepat. Pembahasan ini juga mencakup hasil dari diskusi yang telah dilakukan oleh peneliti dengan pihak hotel yaitu manager hotel Istana. Proses pembahasan yang dilakukan mendapatkan hasil bahwa sistem yang telah dibuat dapat membantu untuk mempermudah pihak manajemen hotel dalam mengontrol produktivitas atau melihat produktivitas pada setiap periode, serta dapat mengetahui faktor apa yang menyebabkan peningkatan ataupun penurunan produktivitas, untuk kemudian dapat dilakukan evaluasi terhadap faktor yang menyebabkan penurunan produktivitas.

Hasil diskusi juga membahas mengenai kelebihan dan juga kelemahan sistem informasi pengukuran produktivitas. Kelebihan dan kekurangan sistem, yaitu :

\section{Kelebihan Sistem}

Dari hasil pembuatan sistem informasi pengukuran produktivitas hotel, penulis dapat menganalisis kelebihan dari sistem yang dibuat yaitu : a. Pengguna harus melakukan login jika ingin menggunakan sistem. Hal ini dimaksudkan untuk keamanan data yang dimiliki oleh pengguna.

b. Data perhitungan yang dihasilkan oleh sistem akurat karena perhitungan dilakukan oleh sistem sehingga hasil perhitungan metode objective matrix dan AHP yang dihasilkan bernilai benar.

c. Sistem mampu menampilkan pesan ketika terjadi error. Hal ini memudahkan pengguna untuk mengetahui bahwa terjadi kesalahan pada saat menjalankan sistem.

d. Sistem ini bersifat dinamis karena nilai pembobotan menggunakan AHP yang digunakan dalam penelitian ini dapat diubah sesuai dengan perkembangan.

\section{Kelemahan Sistem}

Dari hasil pembuatan sistem informasi pengukuran produktivitas hotel, penulis dapat menganalisis kelemahan dari sistem yang dibuat yaitu :

a. Sistem yang dibuat memiliki kekurangan yakni jumlah dari kriteria tidak dapat ditambah atau dikurangi. Hal ini disesuaikan dengan jumlah departemen pada hotel Istana yang memiliki pengaruh terhadap produktivitas hotel.

b. Sistem informasi pengukuran produktivitas hotel ini menggunakan metode objective matrix dimana pada metode tersebut dibutuhkan data aktual pencapaian selama beberapa dari instansi yang bersangkutan, pada penelitian ini data didapat dari dari hotel Istana yang dijadikan sebagai objek penelitian, sehingga jika diterapkan pada hotel lain maka perhitungan nilai produktivitas kurang akurat

\section{KESIMPULAN}

Kesimpulan dari penelitian yang telah dilakukan adalah: a. Penerapan metode objective matrix dan AHP yang digunakan pada sistem informasi pengukuran produktivitas hotel digunakan untuk memberikan nilai indeks produktivitas yang digunakan sebagai penentu peningkatan atau penurunan produktivitas. Langkah awal yakni menentukan nilai bobot prioritas setiap kriteria berdasarkan tingkat kepentingannya dengan menggunakan metode AHP. Selanjutnya dilakukan perhitungan produktivitas dengan memilih periode pengukuran, sehingga menghasilkan skala performansi dari setiap kriteria yang ada. Setelah skala performansi didapatkan, maka nilai tersebut akan diberi skor sesuai dengan matrik omax yang telah dibuat sebelumnya, kemudian skor tersebut akan dikalikan dengan bobot prioritas yang dihitung menggunakan metode AHP sehingga diperoleh nilai indikator performansi. Setelah indikator performansi didapat, maka dibandingkan dengan indikator performansi periode sebelumnya, sehingga diperoleh nilai indeks produktivitas. Nilai indeks produktivitas tersebut digunakan untuk mengetahui pada periode tersebut sedang mengalami peningkatan atau penurunan produktivitas. Selain itu juga dapat mengetahui faktor apa yang menyebabkan peningkatan maupun penurunan produktivitas tersebut.

b. Implementasi metode objective matrix pada sistem ini menggunakan lima rasio yaitu rasio antara jumlah kamar yang dihuni dan jumlah kamar yang tersedia, rasio antara jumlah kamar yang dibersihkan dengan jumlah hari perawatan kamar, rasio antara jumlah porsi food \& beverage dan jumlah pengadaan bahan baku, rasio antara 
jumlah absen karyawan dan jumlah karyawan serta rasio jumlah perbaikan oleh engineering dan jumlah kerusakan sarana. Kelima rasio yang telah ditentukan tersebut berdasarkan pengumpulan data dan studi literatur yang telah ditentukan bobotnya berdasarkan skala kepentingan masing-masing rasio dengan menggunakan metode AHP.

c. Sistem informasi pengukuran produktivitas hotel dengan metode objective matrix dan AHP ini mampu menghasilkan nilai skala performansi, kategori skala, indikator performansi dan indeks produktivitas pada setiap periode, sehingga dapat membantu pihak manajemen hotel dalam mengontrol produktivitas, serta dapat mengetahui fakor apa yang menyebabkan peningkatan ataupun penurunan produktivitas sehingga evaluasi dapat dilakukan pada faktor yang menyebabkan penurunan produktivitas pada periode tersebut.

Saran

Adapun saran yang ditujukan untuk memberikan masukan yang lebih baik yaitu :

a. Sistem informasi pengukuran produktivitas hotel yang akan dikembangkan selanjutnya akan lebih baik jika jumlah kriteria bisa ditambahkan melalui sistem agar bisa menyesuaikan dengan kebutuhan pihak hotel.

b. Sistem informasi pengukuran produktivitas hotel yang akan dikembangkan selanjutnya akan lebih baik jika data aktual pencapaian hotel selama periode tertentu dapat diubah melalui sistem sehingga metode objective matrix pada sistem ini dapat diterapkan pada hotel manapun.

\section{DAFTAR PUSTAKA}

[1] Agustina, F., \& Riana, N. A. (2011, Mei 14). Analisis Produktivitas dengan Metode Objective Matrix (OMAX) di PT.X. Jurnal Teknik dan Manajemen Industri.

[2] Brojonegoro PS, B. (1992). AHP (the Analytical Hierarchy Process). Pusat Antar University - Studi Ekonomi Universitas Indonesia.

[3] Fiati, R. (2015). Pendekatan Model Objective MatrixAHP untuk Pengambilan Keputusan Penilaian Kinerja Pelayanan pada Kantor Kelurahan. Jurnal Teknik Informatika UMK.

[4] Pressman, R. S. (2001). Software Engineering a practitioner's approach (5 ed.). New York, America: McGraw-Hill.

[5] Saaty. (1994). Analytical Hierarchy Process. Bandung: Alfabeta.

[6] Silalahi, d. (2014). Usulan Strategi Peningkatan Produktivitas Berdasarkan Hasil Analisis Pengukuran Objective Matrix (OMAX) pada Departemen Produksi Transformer. Jurusan Teknik Industri Itenas.

[7] Sommerville, I. (2001). Software Engineering. Addison Wesley. 